\title{
ПІДСИСТЕМИ МІСТОБУДІВНОГО МОНІТОРИНГУ ЗЕМЕЛЬ НАСЕЛЕНИХ ПУНКТІВ
}

\section{В. А. Смілка}

Департамент містобудування та архітектури виконавчого органу Київської міської ради

(Київської міської державної адміністрації)

вул. Хрещатик, 32, м. Київ, 01001, Україна. E-mail: smilka@kga.gov.ua

Запропоновано на місцевому рівні державного управління організувати єдину моніторингову систему, що опрацьовує дані для містобудівного моніторингу, моніторингу довкілля та моніторингу земель. Використовуючи системний підхід описано сутність новостворюваної системи містобудівного моніторингу земель населених пунктів та запропоновано її структурну декомпозицію. До складу системи входять такі підсистеми: 1) підсистема збору інформації (включає підсистеми збору профільних даних, тематичних спостережень, конвертації даних та обміну інформацією); 2) аналітична підсистема (включає підсистеми узагальнення інформації, контролю нормативних показників, прогнозування та підтримки прийняття управлінських рішень); 3) презентаційна система (включає підсистеми генерування та оприлюднення результатів моніторингу). Система управління земельними ресурсами потребує постійного удосконалення. Сучасний рівень інформатизації та технічного забезпечення органів місцевого самоврядування дозволяє опрацьовувати великі обсяги різнопрофільної інформації для прийняття управлінських рішень. Пропозиції з інтеграції інформаційних ресурсів різногалузевих моніторингів в єдиній системі утворились на підставі аналізу нормативного забезпечення моніторингів. Зокрема, з'ясовано, що їх внутрішні процеси ідентичні, а множини об'єктів спостереження перетинаються між собою та просторово близькі. Таким чином, збір та опрацювання даних можна здійснювати комплексно. Оброблення даних в єдиному інформаційному середовищі підвищить якість управлінських рішень 3 територіального розвитку у зв'язку паралельним залученням знань про об'єкти спостережень з таких галузей, як екологія, землевпорядкування та містобудування.

Ключові слова: містобудівний моніторинг, моніторинг земель, моніторинг довкілля, населений пункт, система, підсистема.

\section{ПОДСИСТЕМЫ ГРАДОСТРОИТЕЛЬНОГО МОНИТОРИНГА ЗЕМЕЛЬ НАСЕЛЕННЫХ ПУНКТОВ}

\section{В. А. Смилка}

Департамент градостроительства и архитектуры исполнительного органа Киевского городского совета

(Киевской городской государственной администрации)

ул. Крещатик, 32, г. Киев, 01001, Украина. E-mail: smilka@kga.gov.ua

Предложено на местном уровне государственного управления организовать единую мониторинговую систему, обрабатывающую данные для градостроительного мониторинга, мониторинга окружающей среды и мониторинга земель. Используя системный подход описано сущность создаваемой системы градостроительного мониторинга земель населенных пунктов и предложено ее структурную декомпозицию. В состав системы входят следующие подсистемы: 1) подсистема сбора информации (включает подсистемы сбора профильных данных, тематических наблюдений, конвертации данных и обмена информацией); 2) аналитическая подсистема (включает подсистемы обобщения информации, контроля нормативных показателей, прогнозирования и поддержки принятия управленческих решений); 3) презентационная система (включает подсистемы генерирования и обнародования результатов мониторинга). Система управления земельными ресурсами требует постоянного совершенствования. Современный уровень информатизации и технического обеспечения органов местного самоуправления позволяет обрабатывать большие объемы разнопрофильной информации для принятия управленческих решений. Предложения по интеграции информационных ресурсов разноотраслевых мониторингов в единой системе образовались на основании анализа нормативного обеспечения мониторингов. В частности установлено, что их внутренние процессы идентичны, а множества объектов наблюдения пересекаются между собой и пространственно близкими. Таким образом, сбор и обработку данных можно осуществлять комплексно. Обработка данных в единой информационной среде повысит качество управленческих решений по территориальному развитию в связи с параллельным использованием знаний об объектах наблюдений из таких отраслей, как экология, землеустройство и градостроительство.

Ключевые слова: градостроительный мониторинг, мониторинг земель, мониторинг окружающей среды, населенный пункт, система, подсистема.

АКТУАЛЬНІСТЬ РОБОТИ. Регулювання земельних відносин та містобудівна діяльність - важлива тема для фахівців, громадськості та суспільства в цілому. Земельне та містобудівне планування є двома складовими місцевого (міського) управління, i не може бути розмежування між ними, але необхідно розрізняти специфічні інструменти кожного виду планування [1]. Наприклад, розроблення генерального плану населеного пункту технологічно відрізняється від розроблення детального плану території, в складі якого передбачається опрацювання пропозиції та намірів використання нерухомого майна їх власників та користувачів. В складі розроблення містобудівної документації та планування території залучається інструментарій як містобудівного так i земельного проектування.

Прийняттю управлінських рішень в землекористуванні і містобудуванні має передувати аналіз інформації про стан навколишнього середовища, технічний стан забудови та інфраструктури та інших 
періодично поновлюваних даних. Сучасне земельне та містобудівне планування має на меті пошук кращих умов для здоров'я та безпеки людей, економічного розвитку для громади. Досягнення цієї мети можливе шляхом паралельного залучення знань 3 таких галузей: землевпорядкування, містобудування, екологія, теорія управління. Об'єднання знань в цілісний інформаційний ресурс може забезпечити система моніторингу на місцевому рівні, на рівні прийняття управлінських рішень, де перетинаються діаметрально протилежні інтереси багатоцільових груп та організаційних структур.

В України діють окремі системи галузевих моніторингів, зокрема, моніторинг довкілля, моніторинг земель та містобудівний моніторинг. Необхідно розробити принципи, методи взаємозв'язку між цими системами на місцевому рівні для обгрунтованого прийняття управлінських рішень.

У наукових працях 3 проблематики розроблення систем спостереження на місцевості останніми роками висвітлюються результати досліджень за такими основними напрямами:

- методичне забезпечення тематичних моніторингів [2-4];

- питання впровадження системного аналізу в складі тематичних моніторингових систем [5];

- вдосконалення методів оцінювання якості геопросторових даних $[6,7]$.

Питання розроблення комплексної системи моніторингу, що інтегрує знання землевпорядкування та містобудування в населених пунктах розглядались в аспекті організаційно-методичного забезпечення [8]. Проблематика розроблення системи моніторингу в населених пунктах, що інтегрує інформаційні ресурси моніторингу довкілля, моніторингу земель та містобудівного моніторингу системно не досліджувалась.

Метою статті є обгрунтування складу підсистем комплексної системи містобудівного моніторингу земель населеного пункту.

Метод дослідження: системний аналіз, структурний аналіз, узагальнення, синтез.

МАТЕРІАЛ I РЕЗУЛЬТАТИ ДОСЛІДЖЕНЬ. Згідно з Законом України «Про охорону навколишнього природного середовища» від 25.06.1991 р. № 1264-XII з метою забезпечення збору, обробки, збереження та аналізу інформації про стан навколишнього природного середовища, прогнозування його змін та розробки науково обгрунтованих рекомендацій для прийняття ефективних управлінських рішень в Україні створюється система державного моніторингу навколишнього природного середовища.

На виконання цього законодавчого положення прийнята постанова Кабінету Міністрів України від 23.09.1993 № 785 «Про затвердження Положення про державний моніторинг навколишнього природного середовища», однак у 1998 році вона втратила чинність у зв'язку з прийняттям постанови Кабінету
Міністрів України від 30.03.1998 № 391 «Про затвердження Положення про державну систему моніторингу довкілля».

Інфраструктура системи моніторингу довкілля, іiі складові частини визначаються технічним завданням та проектами. Визначено, що моніторинг земель, моніторинг лісів, моніторинг вод та моніторинг атмосферного повітря є складовими частинами державної системи моніторингу довкілля.

Ведення моніторингу земель в Україні передбачено Земельним Кодексом 1990 року в рамках формування законодавчої бази сучасної України. Нормативне забезпечення системи втілено постановою Кабінету Міністрів України від 20.08.1993 р. № 661 шляхом затвердження Положення про моніторинг земель. Сучасне визначення моніторингу земель наведено в ст. 191 Земельного кодексу України, прийнятого у 2002 році. Моніторинг земель $є$ системою спостережень за станом земель, яка має на меті своєчасне виявлення змін у стані земель, їх оцінки, відвернення та ліквідації наслідків негативних процесів. Моніторинг земель складається із систематичних спостережень за станом земель (агрохімічна паспортизація земельних ділянок, зйомка, обстеження і вишукування), виявлення у ньому змін, а також проведення специфічних видів оцінки.

Згідно з Законом України «Про регулювання містобудівної діяльності» створюється система містобудівного моніторингу, як одна з функцій містобудування та містобудівного кадастру. Мінрегіоном України прийнятий порядок проведення містобудівного моніторингу. Склад системи містобудівного моніторингу нормативно не визначений.

Узагальнена схема внутрішніх процесів галузевих моніторингів наведена на рис. 1.

3 врахуванням вищевикладеного, під час напрацювання пропозицій до складу підсистеми цілісної комплексної системи містобудівного моніторингу необхідно спиратись на глибокі теоретичнопрактичні дослідження галузевих моніторингів шляхом врахування сучасних методів розроблення систем.

Ідентичність внутрішніх процесів моніторингів при обробленні первинних даних на місцевому рівні систем галузевих моніторингів дозволяють висувати ідею щодо створення комплексного містобудівного моніторингу земель на рівні населеного пункту.

Місцеві рівні галузевих моніторингів, галузевих кадастрів та планування території $є$ найбільш складними, детальними, точними, оскільки опрацьовують первинні документи, результати вишукувань, містобудівну та проектну документацію. Похибки на місцевому рівні призводять до спотворення даних на вищих рівнях системи.

Головне завдання використання земель в межах населених пунктів полягають у розміщенні міст, селищ і сіл, забезпеченні їх подальшого функціонування та сталого розвитку. 

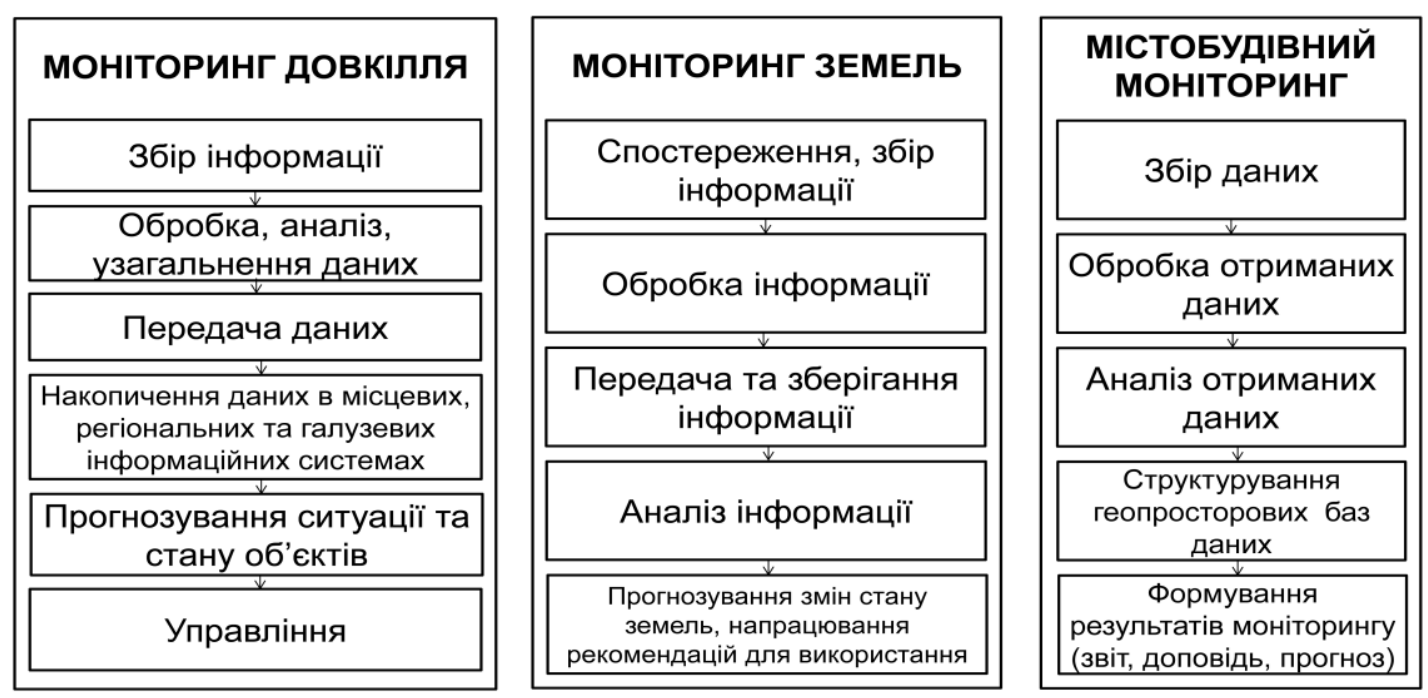

Рисунок 1 - Внутрішні процеси галузевих моніторингів

Верховною радою України у 1999 році схвалено Концепцією сталого розвитку населених пунктів. Проблематика стану розвитку населених пунктів на момент прийняття документу залишається в державі актуальною і до сьогодні. Населені пункти України формуються із значною різницею в рівнях їх соціально-економічного розвитку. Спостерігається перебільшена концентрація населення і виробництва у великих містах. Разом з тим, існує дефіцит зелених та рекреаційних територій. У більшості середніх і малих міст, селищ і сіл спостерігається неефективний, уповільнений розвиток. Це є наслідком втручання держави до регіональної політики протягом тривалого періоду, що призвело до значної дисгармонії територіального та економічного розвитку країни, суттєвих вад у територіальній організації суспільства та системі поселень, погіршення демографічної ситуації в країні, стану зайнятості, зниження якості життя населення, певною мірою зумовило занепад сільської місцевості. В усіх областях України посилюються процеси зменшення чисельності населення.

Структура населених пунктів 3 часом також зазнає змін у зв'язку з вищевикладеним. Динаміка змін кількості населених пунктів наведена у табл. 1 . Зменшення кількості сільських населених пунктів пояснюється тим, що населення мігрує до міст, занепадає монофункціональне сільське виробництво не розвивається інфраструктура населених пунктів. Зменшення кількості селищ пояснюється тим, що їх частина також занепадає, а інша частина набуває статусу міст у наслідок розвитку та збільшення чисельності населення.

Водночас, зі зменшенням кількості населених пунктів спостерігається тенденція збільшення загальної площі територій населених пунктів. При цьому землі використовуються нераціонально, здебільшого це стосується земель, відведених під об'єкти промисловості, транспорту, енергетики, а також землі рекреаційного призначення. Через недостатність коштів місцевих бюджетів повільно розробляються (коригуються) генеральні плани населених пунктів, інша містобудівна документація, яка $є$ основою для вирішення питань щодо забезпечення збалансованого використання територій. Особливо гостро така проблема стоїть для сільських населених пунктів та новостворених об'єднаних територіальних громад.

Таблиця 1 - Динаміка змін кількості населених пунктів в Україні

\begin{tabular}{|c|c|c|c|c|c|}
\hline \multirow{2}{*}{$\begin{array}{c}\text { Тип населе- } \\
\text { ного пункту }\end{array}$} & \multicolumn{4}{|c|}{ Кількість населених пунктів, станом на } \\
\cline { 2 - 6 } & 1990 & $\begin{array}{c}01.01 . \\
2001\end{array}$ & $\begin{array}{c}01.01 . \\
2011\end{array}$ & $\begin{array}{c}01.01 . \\
2018\end{array}$ & $\begin{array}{c}\text { Різниця } \\
\text { за 27 } \\
\text { років }\end{array}$ \\
\hline Місто & 436 & 451 & 459 & 460 & 24 \\
\hline $\begin{array}{c}\text { Селище } \\
\text { міского } \\
\text { типу }\end{array}$ & 927 & 892 & 885 & 885 & -42 \\
\hline $\begin{array}{c}\text { Сільський } \\
\text { населений } \\
\text { пункт }\end{array}$ & 28804 & 28619 & 28457 & 28377 & -427 \\
\hline Разом & 30167 & 29962 & 29801 & 29722 & -445 \\
\hline
\end{tabular}

В межах населених пунктів включені різні за категоріями землі, зокрема, згідно з формою 6-зем, станом на 01.01.2016 в населених пунктах налічується:

- сільськогосподарські землі: 5107 тис. га (67,4 \%);

- ліси на інші лісовкриті площі: 356 тис. га (4,7 \%);

- забудовані землі: 1698 тис. га (22,4 \%);

- відкриті землі (заболочені та землі без рослинного покриву або з незначним покривом): 255 тис. га $(3,4 \%)$;

- води: 165 тис. га $(2,1 \%)$.

Частка земель населених пунктів в України невпинно збільшується, динаміка зміни площ населених пунктів наведена на рис. 2.

В Україні в межах населених пунктів обліковується понад 75 \% від загальної кількості землевласників та землекористувачів країни. Реалізація земельної реформи в Україні спричиняє збільшення кількості землевласників та землекористувачів, зокрема в населених пунктах, що в свою чергу впливає на динамічність містобудівної діяльності та економічне зростання. 


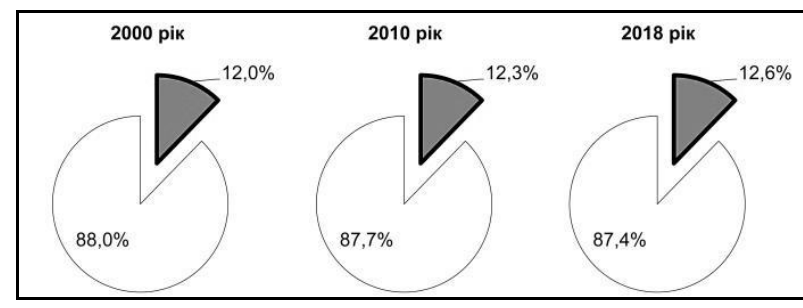

Рисунок 2 - Динаміка зміни загальної площі населених пунктів в Україні

Декомпозиція у системному аналізі полягає в розбитті системи на підсистеми і вивчення підсистем, задачі - на підзадачі, цілей - на підцілі [9]. Процес декомпозиції завжди здійснюється на основі певної моделі системи. За основу береться модель і, відповідно до неї, виконується декомпозиція. Найбільш часто декомпозиція здійснюється за моделями «склад системи», «структура системи».

Формальна модель містобудівного моніторингу земель населених пунктів включає предмет діяльності, засіб, об'єкт, суб'єкт і середовище.

Предметом містобудівного моніторингу земель населених пунктів є показники властивості елементів урбанізованих територій. Засобом моніторингу $є$ сучасні технології збирання, оброблення даних, аналізу, прогнозування та представлення його результатів. Об'єктом моніторингу є землі населених пунктів. Суб'єктами моніторингу є суб'єкти землевпорядкування, містобудування та екологічної діяльності. Моніторингова діяльність зосереджена в межах населених пунктів в середовищі щільного скупчення людей.

До основних завдань містобудівного моніторингу земель населених пунктів належать:

1) запровадження системи періодичних повторюваних спостережень за середовищем та об'єктами в межах населеного пункту шляхом збору інформації та фіксації змін елементів, моделювання, оцінки і прогнозування стану параметрів та характеристик об'єктів, явищ і негативних процесів, що є наслідком містобудівної діяльності або впливають на неї;

2) вдосконалення структури моніторингових досліджень в межах населених пунктів з метою систематизації інформації, усунення дублювання інформації, налагодження взаємодії між підрозділами, що здійснюють спостереження за просторовими об'єктами;

3) впровадження можливості математичного моделювання для оптимізації містобудівних, землевпорядних та управлінських рішень;

4) забезпечення інформаційного зв'язку між міськими системами, галузевими кадастрами.

Шляхом агрегування внутрішніх процесів моніторингу можна їх об'єднати в наступні технологічні групи:

- технічна, що забезпечує збір, оброблення даних;

- аналітична, що забезпечує аналіз інформації та прогнозні розрахунки стану середовища;

- презентаційна, що забезпечує представлення результатів моніторингу, в тому числі за допомогою сучасних інформаційних технологій, таких як геоінформаційні системи та веб-технології.

Перелік зазначених груп є основою для формування переліку підсистем містобудівного моніторингу земель населених пунктів.

Система моніторингу повинна забезпечити можливість здійснення спостережень за всіма категоріями земель та виокремлення їх специфічних властивостей. Тому до формування складу підсистем необхідно застосувати підходи декомпозиції за функціональними та технологічними ознаками.

Системне узагальнення підходів до функціональних видів моніторингу довкілля знайшло відображення у його класифікаціях, які створювались різними авторами. Кожна класифікація має свою специфіку та залежить від обраних автором принципів іiї формування. Власну класифікацію моніторингу довкілля, яка спитається на принципи вибору системи спостережень, запропонував Ю. А. Ізраель $[10,11]$. Окремі положення з цієї класифікації, які наведені у табл. 2, на нашу думку можуть застосовуватись при дослідженні системи містобудівного моніторингу земель.

Таблиця 2 - Фрагмент класифікації систем (підсистем) моніторингу довкілля за Ю. А. Ізраелем

\begin{tabular}{|c|c|}
\hline $\begin{array}{c}\text { Принципи } \\
\text { класифікації }\end{array}$ & $\begin{array}{c}\text { Наявні чи розроблювані системи } \\
\text { (підсистеми) моніторингу }\end{array}$ \\
\hline $\begin{array}{l}\text { Різні } \\
\text { середовища }\end{array}$ & $\begin{array}{l}\text { Моніторинг антропогенних змін } \\
\text { в атмосфері, гідросфері, грунті, } \\
\text { кріосфері, біоті }\end{array}$ \\
\hline $\begin{array}{l}\text { Фактори і } \\
\text { джерела } \\
\text { впливу }\end{array}$ & $\begin{array}{l}\text { Моніторинг джерел забруднень. } \\
\text { Інгредієнтний моніторинг } \\
\text { (наприклад, окремих забрудню- } \\
\text { вальних речовин, радіоактивних } \\
\text { випромінювань, шумів) }\end{array}$ \\
\hline $\begin{array}{l}\text { Методи } \\
\text { спостережень }\end{array}$ & $\begin{array}{l}\text { Моніторинг за фізичними, } \\
\text { хімічними і біологічними } \\
\text { показниками. } \\
\text { Супутниковий моніторинг } \\
\text { (дистанційні методи) }\end{array}$ \\
\hline
\end{tabular}

Як видно, до нормативного структурування системи моніторингу довкілля застосовувались наукові принципи організації спостережень у різних середовищах. Специфічними складовими підсистеми моніторингу довкілля для населених пунктів $є$ множина середовищ, зокрема атмосферне повітря, наземні та підземні води, а також грунти.

У наукових колах існує думка, що склад підсистем моніторингу земель ідентичний категоріям земель [12]. Таким чином мають формувались характерні підсистеми моніторингу сільськогосподарських земель, лісів, забудованих земель, заболочених земель та вод.

3 метою виявлення специфічних підсистем містобудівного моніторингу та побудови його структури необхідно провести аналіз законодавчонормативних документів та науково-методичної літератури в сфері містобудування та архітектури. В українському законодавстві наводяться поняття «моніторинг забудови і іншого використання тери- 
торії», «моніторинг реалізації Генеральної схеми планування території України», «моніторинг забудови», «моніторинг стану розроблення та реалізації містобудівної документації». В нормативних документах зустрічаються поняття «містобудівний моніторинг об'єктів», «моніторинг стану розроблення генеральних планів населених пунктів, планів зонування територій (зонінгів) та детальних планів території», «моніторинг об'єктів», «моніторинг динамічних процесів у складі, стані і характеристиці об'єктів», «містобудівний моніторинг». В науковометодичній літературі досліджуються проблеми «архітектурного моніторингу», «містобудівного моніторингу» та «міського моніторингу».

Шляхом групування подібних за змістом та внутрішньою суттю понять пропонуємо сформувати таку структуру містобудівного моніторингу:

1. Моніторинг реалізації містобудівної документації, як підсистема обліку, аналізу та оцінки фактичних змін характеристик об'єктів містобудування і соціально-економічного стану території, в порівняні 3 проектними показниками, які затверджені містобудівною документацією і спрямовані на забезпечення сталого розвитку територій 3 урахуванням державних і громадських інтересів.

2. Моніторинг забудови. Для здійснення аналізу зміни параметрів містобудівної документації необхідно обліковувати зміну параметрів конкретних об’єктів будівництва або груп таких об'єктів за принципом від загального до часткового. Множина об’єктів будівництва утворює забудову. Разом з тим, моніторинг забудови може стосуватись об'єктів, параметри яких не затверджені містобудівною документацією. Поняття «забудова» можна розглядати як процес і як предмет. В даному дослідженні поняття «забудова» сприймаємо, як предмет, що означає капітальну будівлю (групу будівель), споруджену, або таку, що будується на земельній ділянці для задоволення потреб людини.

3. Моніторинг інфраструктури населеного пункту (територіi). Інфраструктура має розгалужену мережу і може мати свої елементи за межами населених пунктів та забудованих території. Наприклад, транспортна, енергетична інфраструктура. У науковій літературі виділяють окремі види моніторингу інфраструктури, як «транспортно-екологічний моніторинг» та «моніторинг інженерних комунікацій». Метою моніторингу інфраструктури є виявлення, збір, аналіз і систематизація інформації по реалізації комплексного розвитку систем інфраструктури населених пунктів та територій відповідно до містобудівної документації та проектної документації, а також аналіз і оцінка заходів, передбачених програмою комплексного розвитку. Предметною областю моніторингу інфраструктури є об'єкти будівництва (реконструкції) систем электро-, газо-, тепло-, водопостачання і водовідведення, зв'язку, залізничного, автомобільного, в тому числі громадського транспорту, зовнішнього транспорту, вулично-дорожньої мережі. Ведення моніторингу інфраструктури базується на контролі проектних параметрів об'єктів інфраструктури та проведенні вибіркових реальних обстежень об'єктів, визначенні реальних навантажень на мережі $з$ використанням приладів та інструментів. Параметри цих об'єктів є вузькопрофільними і неповторюваними для інших видів інфраструктури.

Важливим елементом для врахування результатів моніторингу є підготовка обгрунтовуючих матеріалів для прийняття управлінських рішень.

Управління - функція організованих систем, яка забезпечує збереження їх структури, підтримання режиму діяльності, реалізацію іiі програми і цілі. Основні етапи процесу управління: 1) збір і обробка інформації; 2) аналіз, систематизація (синтез), діагноз і прогноз, встановлення на цій основі мети (цілеспрямованості системи); 3) розробка рішення, спрямованого на досягнення мети; 4) послідовна конкретизація рішення у вигляді планування, проектування, вироблення конкретних рішень; 5) організація діяльності для виконання рішення; 6) контроль за цією діяльністю; 7) збір і обробка інформації про результати діяльності і новий цикл цього безперервного процесу [5].

Моніторинг є однією з підсистем у великій системі управління населеним пунктом. Значна частина процесів управління досягається шляхом проведення спостережень за середовищем в межах населеного пункту [13]. Необхідно зберегти цілісність системи управління на місцевому рівні шляхом передбачення у новостворюваній системі моніторингу земель підсистеми сприяння прийняттю управлінських рішень. Зазначена підсистема має функціонувати в складі аналітичної підсистеми, призначеної для виявлення проблемних ситуацій та напрацювання варіантів їх розв'язання, моделювання сценаріїв розвитку подій.

Шляхом узагальнення результатів дослідження моніторингу земель населених пунктів формується його модель, що інтегрує технологічні та тематичні аспекти спостережень за множиною об’єктів. До складу моделі системи входять такі підсистеми:

1. Підсистема збору інформації (включає підсистеми збору профільних даних, тематичних спостережень, конвертації даних та обміну інформацією);

2. Аналітична підсистема (включає підсистеми узагальнення інформації, контролю нормативних показників, прогнозування, підтримки прийняття управлінських рішень);

3. Презентаційна система (включає підсистеми генерування та оприлюднення результатів моніторингу).

Модель системи містобудівного моніторингу земель наведена на рис. 3.

ВИСНОВКИ. Містобудівний моніторинг земель населених пунктів слід розглядати як складову системи управління населеним пунктом, що опрацьовує набір відомостей та показників, що характеризують екологічні, містобудівні, економічні фактори. Декомпозиція системи містобудівного моніторингу на складові підсистеми та побудова моделі дозволяють зрозуміти взаємозв'язок всіх iї компонентів, які підтримують цілісність системи. 


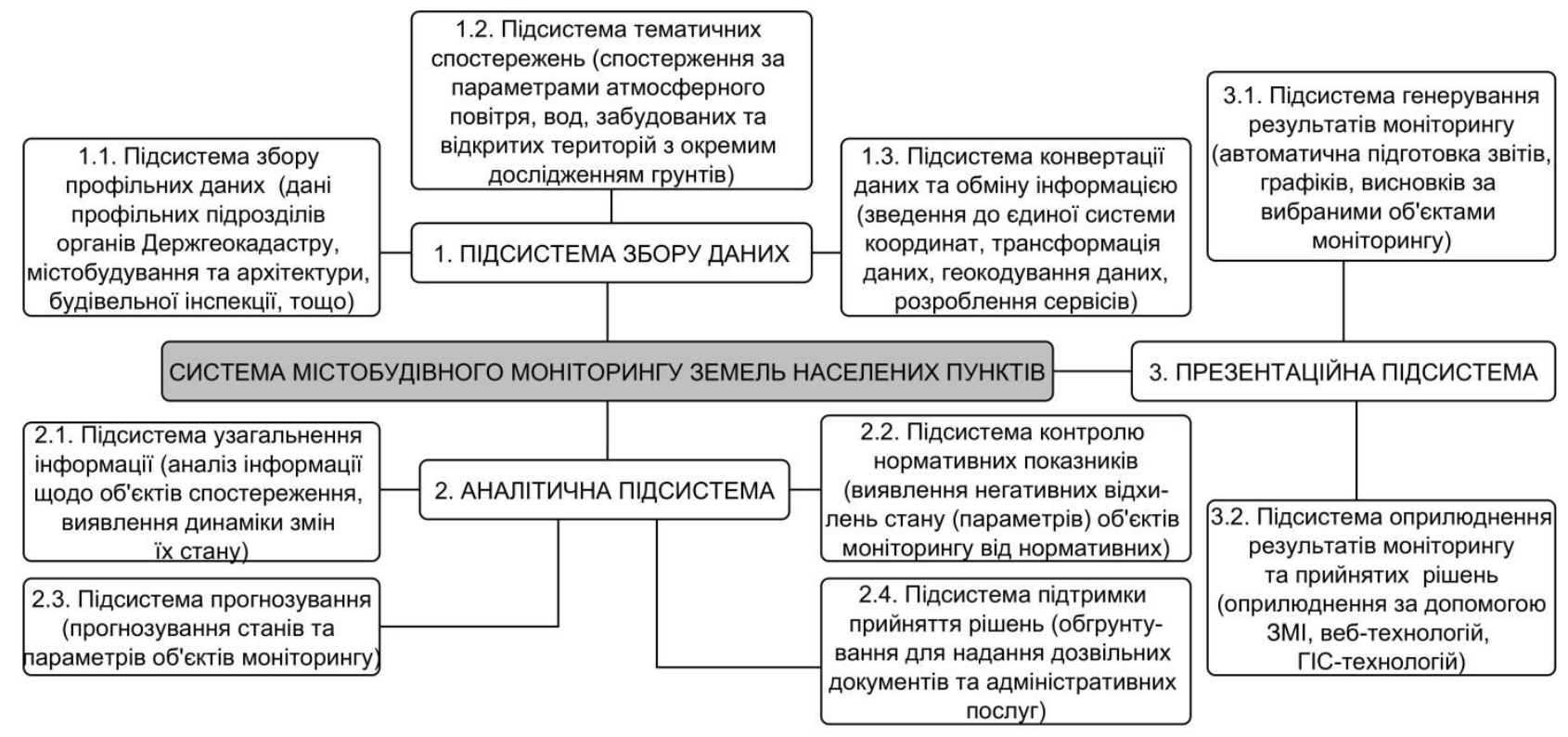

Рисунок 3 - Модель системи містобудівного моніторингу земель населених пунктів

Наступними етапами побудови системи містобудівного моніторингу земель населених пунктів $\epsilon$ розроблення інформаційної моделі системи, затвердження класифікаторів та кодифікаторів даних, розроблення структури бази геопросторових даних.

\section{ЛІТЕРАТУРА}

1. Maria Cristina Treu. Governing land and urban change: the approaches. City, Territory and Architecture, 2017. Vol. 4:18 URL: https://link.springer.com/article/10.1186/s40410-0170075-z.

2. Бахарєв В. С. Недосконалість існуючої системи екологічного моніторингу атмосферного повітря на рівні урбосистеми: причини, наслідки, шляхи вдосконалення. Вісник Кременчуиьького національного університету імені Михайла Остроградського. Кременчук: КрНУ, 2016. Вип. 5 (100). С. 76-81.

3. Шелковська I. М. Сучасна система геоінформаційного моніторингу земель прибережних територій водосховищ. Вісник Кременчуиького національного університету імені Михайла Остроградського. Кременчук: КрНУ, 2015. Вип. 1. С. 139-144.

4. Wolski B. Monitoring of river embankments deformations in flood wave proragation conditions. Reports on Geodesy. Warsaw: Warsaw university if texnology. Institute of geodesy and geodetic astronomy, 2005. Vol 3 (74). P. 254-260.

5. Панова Л. П. Системность архитектурной среды. Харьков, $2010-235$ с.
6. Лященко А. А., Горковчук М. В. Функціональна модель автоматизованої системи контролю та оцінювання якості геопросторових даних. Сучасні досягнення геодезичної науки та виробництва. Львів.: Ліга-Прес, 2014. Вип. 1(27). С. 103-108.

7. Ye, Y. \& A. Van Nes. Quntitative tools and urban morphology: combining space syntax, spacematrix and mixed-use index in GIS framework. Urban morphology, 2014. Vol 18 (2). P. 97-118.

8. Пиркова О. В. Організаційно-методичний меха-нізм формування та використання містобудівного моніторингу земель міст: характеристика й технології реалізації. Комунальне господарство міст. Серія : Технічні науки та архітектури. Харків, 2015. Вип. 124. С. 91-96.

9. Елохов А. М. Системный подход к городу как объекту программно-целевого управления. $A R S$ ADMINISTRANDI, 2011. Вип. 2. С. 61-79.

10. Израэль Ю. А., Груза Г. В., Ранькова Э. Я. Предел предсказуемости и стратегический прогноз изменений климата. Проблемы экологического мониторинга и моделирования экосистем. Москва, ИГКЭ, 2009, Т. XXII. С. 7-26.

11. Ісаєнко В. М., Вовк О. О., Зайченко С. В., Ремез Н. С. Методи прогнозування та моніторингу технонебезпечних динамічних процесів на екземптованих територіях. Київ: НАУ, 2018. 236 с.

12. Антоненко И. В. Мониторинг и охрана городских земель. Челябинск: ЮУрГУ, 2001. 96 с.

13. Шубович С.А., Соловьева О.С., Панова Л. П. Введение в архитектурный мониторинг городской среды. Харьков: ХНАГХ, 2009. 67 с.

\section{V.Smilka}

\section{SUMMARY OF THE CITY MONITORING OF THE LAND OF POPULATION ITEMS}

Department of Urban Development and Architecture of the Executive Body of Kyiv City Council

(Kyiv City State Administration)

vul. Khreshchatyk, 32, Kyiv, 01001, Ukraine. E-mail: smilka@kga.gov.ua

Purpose. To substantiate composition of subsystems of a complex system of town-planning monitoring of settlements. Methodology. System analysis, structural analysis, generalization, synthesis have been used. Results. Modern 
land and town planning is aimed at finding better conditions for people's health and safety and for community economic development. Achievement of this goal is possible through the parallel bringing of knowledge in the following areas: land management, urban development, ecology, management theory, because the internal processes of thematic monitoring carried out within settlements are identical. A complexed monitoring system can provide integration knowledge into a holistic information resource at the local level of government, where intersects the diametrically opposite interests of multi-purpose groups and organizational structures. Such system should ensure the possibility of observing all categories of land, all industrial areas and distinguishing their specific properties. Therefore, the formation of the subsystems requires the application of decomposition approaches by functional and technological features. By summarizing the results of the survey of the monitoring of the settlements, a model is developed that includes the following subsystems: 1. The subsystem of information gathering (includes subsystems for collecting profile data, thematic observations, data conversion and information exchange); 2. Analytical subsystem (includes subsystems of generalization of information, control of normative indicators, forecasting and support for the adoption of managerial decisions); 3. Presentation system (includes subsystems for generation and publication of monitoring results). Originality. At the local level, it is proposed to combine information resources for sectoral monitoring, which monitors geospatial objects, in particular, environmental monitoring, land monitoring and urban monitoring. Practical value. Integration of information resources will avoid duplication of information, solve the problem of the lack of cross-sectoral information during the making a managerial decisions, and will contribute to saving financial, material and labor resources to support a single monitoring service within the settlement. Conclusions. Urban land monitoring of settlements should be considered as a component of the management system of the settlement, which processes a set of data and indicators that characterize environmental, urban, economic factors. Decomposition of the urban land monitoring system into components of the subsystem and the construction of the model, allows us to understand the relationship of all its components that support the integrity of the system. The next stages of building a system of town-planning monitoring of settlements are the development of an information model of the system, the approval of classifiers and data codifiers, the development of the structure of the geospatial data base.

Key words: urban monitoring, land monitoring, monitoring of the environment, settlement, system, subsystem.

\section{REFERENCES}

1. Treu, Maria Cristina (2017), "Governing land and urban change: the approaches" City, Territory and Architecture, vol U:18, URL: https://link.springer.com/article/10.1186/s40410-0170075-z.

2. Bakharev, V. (2016), "The imperfection of the existing system of atmospheric air ecological monitoring at the level of urbosystem: causes, consequences, ways of improving", Transactions of Kremenchuk Mykhailo Ostrohradskyi National University, vol. 5, no. 100, pp. 76-81.

3. Shelkovska, I. M. (2015), "Modern system of geoinformation monitoring of lands of coastal areas of reservoirs", Transactions of Kremenchuk Mykhailo Ostrohradskyi National University, vol. 5, no 90, pp. 139-144.

4. Wolski, B. (2005), "Monitoring of river embankments deformations in flood wave proragation conditions", Reports on Geodesy, vol 3, no 74, pp. 254260.

5. Panova, L. P. (2010), Systemnost' arkhitekturnoho seredovyshcha [System architecture of the architectural environment], Kharkiv, Ukraine.

6. Lyashchenko, A. A., Gorkovchuk, M. V. (2014), "Functional model of the automated system of control and evaluation of geospatial data quality", Modern achievements in geodetic science and production, vol. 1, no 27, pp. 103-108.

7. Ye, Y., Van Nes, A. (2014), "Quntitative tools and urban morphology: combining space syntax, spacematrix and mixed-use index in GIS framework", Urban morphology, vol 18, no 2, pp. 97-118.
8. Pyrkova, O. V. (2016), “Organizational and methodical mechanism of formation of urban planning monitoring of land use", Municipal economy of cities. Series: Engineering and Architecture, vol 18, no 2, pp. 91-96.

9. Yelokhov, A. M. (2011), Sistemnyy podkhod k gorodu kak ob"yektu programmno-tselevogo upravleniya, ARS ADMINISTRANDI, vol. 2, pp. 61-79.

10. Izrael, Yu. A., Gruza, G. V., Rankova, E. YA. (2009), Limit of predictability and strategic prediction of climate change, On Sat Problems of ecological monitoring and modeling of ecosystems, iss. XXII. pp. 7-26.

11. Isayenko, V. M., Vovk, O. O., Zaychenko, S. V., Remez, N. S. (2018), Metody prohnozuvannya ta monitorynhu tekhnonebezpechnykh dynamichnykh protsesiv na ekzemptovanykh terytoriyakh [Methods of forecasting and monitoring of techno-dangerous dynamic processes in the existed territories], Kyiv. Ukraine.

12. Antonenko, I. V. (2001), Monitoring i okhrana gorodskikh zemel' [Monitoring and protection of urban land], Chelyabinsk, Russia.

13. Shubovych, S. A., Solovieva O.S., Panova, L. P. (2009), Vvedeniye v arkhitekturnyy monitoring gorodskoy sredy [Introduction to architectural monitoring of the urban nvironment], Kharkov, Ukraine. 